\title{
KEWENANGAN PT. PELINDO IV TARAKAN TERHADAP HAK ATAS TANAH DAERAH LINGKUNGAN KERJA PELABUHAN
}

\author{
Endy Kurniawan \\ PNS Pemeritah Kota Tarakan \\ Tarakan, Kalimantan Utara, Indonesia \\ ndhee87@yahoo.co.id
}

\begin{abstract}
The title of the research is to " LAW REVIEW THE LAND ENVIRONMENT WORKING OF PORT AREAS (DLKr) PT. PELINDO IV OF TARAKAN. The purpose of this research is to analyze the authority of PT PELINDO IV Tarakan as holders of land rights in the form of Rights Management (HPL) the land environment working of port areas. In addition, the study also to analyze the land of rights can be given to the people on ) the land environment working of port areas or coastal region.

This Research to use normative legal method to study with the type of normative juridical. As for the approach used in this study is the statute approach and conceptual approach. Sources of legal materials used are primary, secondary and tertiary legal material. Legal materials collection techniques used this study to collect and analyze the Regulation in relating to the legal issues raised, as well as collecting the conceptual framework and legal theory to be the basis of analyzing the legal issues studied.

PT. PELINDO IV of Tarakan has the authority to the land environment working of port areas with Right to used (HPL) contained in the Joint Decree of the Minister of Home Affair and Minister of Transportation Number 31 of 1992 K.M Number 9 of 1992 concerning frontier Work Environment Ports. In the fourth dictum of the Joint Decree of the Minister of Home Affair and Minister of Transportation, PT. PELINDO IV of Tarakan required to complete the land registration process in the Land Office in accordance with applicable regulations. Until now PT. Pelindo IV Tarakan not enroll all of the land which they are entitled and limitations affect the authority of PT. Pelindo IV Tarakan on the overall the land environment working of port areas.
\end{abstract}

Keynote : Land Law, HPL, Law Review

\section{PENDAHULUAN}

Tanah dalam pelaksanaan pembangunan merupakan elemen terpenting dan modal negara yang dipergunakan untuk mewujudkan kesejahteraan dan kemakmuran seluruh rakyat, sebab dalam konteks negara Indonesia yang agraris, tanah merupakan faktor utama sumber penghidupan. Dalam UUPA Pasal 9 ayat (2) menyebutkan ; "Tiap- tiap warganegara Indonesia, baik laki-laki maupun wanita mempunyai kesempatan yang sama untuk memperoleh sesuatu hak atas tanah serta untuk mendapat manfaat dan hasilnya, baik bagi diri sendiri maupun keluarganya “. Secara hirarki, hak penguasaan atas tanah terdiri atas hak bangsa Indonesia atas tanah, hak menguasai negara atas tanah, 
hak masyarakat hukum adat/ hak ulayat dan hak- hak perseorangan atas tanah. Hal tersebut dapat diketahui dari pendapat Muhammad Bakri yang menyatakan berdasarkan sifat dan asasnya, hak menguasai tanah oleh negara bersumber dari kewenangan Pemerintah. ${ }^{1}$ lebih lanjut Boedi Harsono juga menyatakan bahwa hak penguasaan atas tanah berisi serangkaian wewenang, kewajiban dan atau larangan bagi pemegang haknya untuk berbuat sesuatu mengenai tanah yang menjadi haknya. Sesuatu yang boleh, wajib atau dilarang untuk diperbuat, yang merupakan isi hak penguasaan itulah yang menjadi tolak ukur pembeda antara hak- hak penguasaan atas tanah yang diatur dalam hukum tanah. ${ }^{2}$ Hak penguasaan atau hak atas tanah bersifat privat dan bersifat publik, hak atas tanah yang bersifat privat lebih kepada hak memiliki atas tanah tersebut, sedangkan hak atas tanah yang bersifat publik lebih pada mengatur dan menentukan kemanfaatan dari tanah tersebut.

Hak atas tanah dalam penerapannya juga dikenal adanya Hak Pengelolaan (selanjutnya disebut HPL) yang muncul sejak tahun 1965 melalui Peraturan Menteri Agraria Nomor 9 Tahun 1965 tentang Konversi Hak Penguasaan Atas Tanah Negara dan Ketentuan- ketentuan tentang Kebijaksanaan Selanjutnya juncto Peraturan Menteri Agraria Nomor 1 Tahun 1966 tentang Pendaftaran Hak Pakai dan Hak Pengelolaan dan dihubungkan dengan Peraturan Pemerintah Nomor 8 Tahun 1953 tentang Penguasaan Tanah - Tanah Negara. ${ }^{3}$ Hak Pengelolaan adalah hak atas tanah Negara seperti yang dimaksud dalam Peraturan Menteri Agraria Nomor 9 Tahun 1965 yang memberi kewenangan kepada pemegang hak itu untuk : ${ }^{4}$ (a) Merencanakan Peruntukan dan penggunaan tanah yang bersangkutan, (b) menggunakan tanah tersebut untuk keperluan pelaksanaan tugasnya. (c) menyerahkan bagian- bagian dari tanah itu kepada pihak ketiga dengan Hak Pakai yang berjangka waktu 6 tahun, (d) menerima uang pemasukan dan/ atau uang wajib tahunan.

Tanah yang merupakan suatu benda yang bernilai ekonomis, sekaligus magisreligio-kosmis menurut pandangan bangsa Indonesia; ia pula yang sering memberi getaran di dalam kedamaian dan sering pula menimbulkan goncangan dalam masyarakat

\footnotetext{
1Muhammad Bakri, Hak Menguasai Tanah Oleh Negara Paradigma Baru Untuk Reforma Agraria, Citra Media, Jakarta, 2007, h. 37.

${ }^{2}$ Boedi Harsono I, Op. Cit, h. 24.

${ }^{3}$ Arie Sukanti Hutagalung dan Markus Gunawan, Kewenangan Pemerintah di Bidang Pertanahan, Rajawali Pers, Jakarta, 2009, h. 51- 52.

${ }^{4}$ G. Kertasapoetra, Masalah Pertanahan di Indonesia, Rineka Cipta, Jakarta, 1992, h. 59- 52.
} 
serta sendatan dalam pelaksanaan pembangunan. ${ }^{5}$ Salah satu pemicu dari timbulnya permasalahan tersebut dikarenakan tatanan norma sering kali tidak sesuai dengan realitas yang terjadi di lapangan. Dinyatakan oleh Hans Kelsen bahwa perlu adanya kesesuaian antara keharusan dalam suatu tatanan norma dan realitas dikarenakan kenyataan mempengaruhi validitas dari tatanan norma itu sendiri. ${ }^{6}$ Dari pendapat tersebut maka penulis mencoba menelaah permasalahan- permasalahan yang telah diungkapkan untuk kemudian dilakukan analisis hukum untuk memperoleh pemahaman hukum dan validitas dari SKB yang menjadi dasar PT. PELINDO IV Tarakan memperoleh wewenang dan Hak Atas Tanah di Daerah Lingkungan Kerja Pelabuhan.

\section{RUMUSAN MASALAH}

Memperhatikan latar belakang tersebut maka penulis akan melakukan penelitian berkaitan dengan permasalahan terkait Kewenangan PT. PELINDO IV Tarakan atas tanah Daerah Lingkungan Kerja Pelabuhan.

\section{PEMBAHASAN}

\section{Kawasan Kepelabuhanan Tarakan.}

Pengertian pelabuhan berasal dari kata Port dan Harbour, namun pengertian tersebut tidak dapat diambil sebagai pengertian pelabuhan secara harfiah. Harbour mempunyai pengertian sebagai perairan yang terlindungi badai, aman dan baik atau cocok bagi akomodasi kapal- kapal untuk berlindung, mengisi bahan bakar, persediaan, perbaikan dan bongkar muat barang. Sementara itu istilah Port adalah harbor yang terlindungi, dimana tersedia fasilitas terminal laut, yang terdiri dari tambatan atau dermaga untuk bongkar muat barang dari kapal, gudang, transit, dan penumpukan lainnya untuk menyimpan barang dalam angka pendek atau angka panjang. ${ }^{7}$ Dari pengertian tersebut, definisi pelabuhan mencakup prasarana dan sistem transportasi, yaitu suatu lingkungan kerja terdiri dari area daratan dan perairan yang dilengkapi fasilitas pendukung lainya.

Pelabuhan sendiri diatur pada Peraturan Pemerintah Nomor 61 tahun 2009 tentang Kepelabuhanan, Lembaran Negara (LN) Republik Indonesia tahun 2009 Nomor 151; kemudian dirubah dengan Peraturan Pemerintah Nomor 64 Tahun 2015 tentang Perubahan atas Peraturan Pemerintah Nomor 61 Tahun 2009 tentang Kepelabuhanan,

\footnotetext{
5John Salindeho, Masalah Tanah dalam Pembangunan, Sinar Grafika, Jakarta, 1988, h. 23.

${ }^{6}$ Hans Kelsen, Teori Umum Tentang Hukum dan Negara, Nusa Media, Bandung, 2014, h. 174.

${ }^{7}$ Elfrida Gultom, Refungsionalisasi Pengaturan Pelabuhan untuk Meningkatkan Ekonomi Nasional, Raja Grafindo Persada, 2007, h. 22.
} 
Lembaran Negara (LN) Republik Indonesia Tahun 2015 Nomor 193. yang merupakan turunan dari Undang- Undang Nomor 17 Tahun 2008 tentang Pelayaran, Lembaran Negara (LN) Republik Indonesia Tahun 2008 Nomor 64. Peran strategis pelabuhan dalam sistem transportasi khususnya transportasi laut sangat penting bagi Indonesia yang merupakan negara kepulauan. berdasarkan Peraturan Menteri Perhubungan Nomor 51 Tahun 2015 tentang Penyelenggaraan Pelabuhan Laut, Berita Negara Republik Indonesia Tahun 2015 Nomor 311 (selanjutnya disebut Permenhub Nomor 51 Tahun 2015); fungsi pelabuhan merupakan penunjang kelancaran, keamanan dan ketertiban arus lalu lintas kapal, penumpang dan/atau barang, keselamatan dan keamanan berlayar, tempat perpindahan intra- dan/ atau antarmoda, serta mendorong perekonomian nasional dan daerah dengan tetap memperhatikan tata ruang wilayah.

Kawasan Kepelabuhanan terdiri atas perairan dan daratan, Pada Peraturan Pemerintah Nomor 61 tahun 2009 tentang Kepelabuhanan dikenal adanya istilah Daerah Lingkungan Kerja Pelabuhan dan Daerah Lingkungan Kepentingan Pelabuhan. Daerah Lingkungan Kerja Pelabuhan (DLKr) adalah wilayah perairan dan daratan pada pelabuhan umum yang dipergunakan secara langsung untuk kegiatan kepelabuhanan. Sedangkan Daerah Lingkungan Kepentingan Pelabuhan (DLKp) adalah wilayah perairan di sekeliling daerah lingkungan kera perairan pelabuhan umum yang dipergunakan untuk menjamin keselamatan pelayaran. Sebagian besar dari Daerah Lingkungan Kerja Pelabuhan (DLKr) adalah daratan, hal tersebut dikarenakan fasilitas pokok pelabuhan dan fasilitas penunjang pelabuhan seperti dermaga, gudang, lapangan penumpukan lini 1, terminal penumpang, terminal petikemas, kawasan perkantoran dan yang lainnya berada pada Daerah Lingkungan Kerja pelabuhan (DLKr) yang merupakan daratan.

Berdasarkan SKB Menteri Dalam Negeri dan Menteri Perhubungan RI Nomor 31 Tahun 1992 Nomor K.M 9 Tahun 1992 tentang batas- batas daerah Lingkungan Kerja Pelabuhan, dapat diketahui batas- batas lingkungan Kerja yang menjadi wilayah kerja PT. PELINDO IV Tarakan. SKB Menteri Dalam Negeri dan Menteri Perhubungan tersebut didasari oleh Keputusan Menteri Dalam dan Menteri Perhubungan Nomor 191 Tahun 1969 / SK 83/0/1969 yang dikeluarkan tanggal 27 Desember 1969 tentang Penyediaan dan penggunaan Tanah untuk keperluan Pelabuhan serta Surat Gubernur Kepala Daerah Tingkat I Kalimantan Timur Nomor 651/ 626/ BPD. 1 BANG tanggal 13 Januari 1987 prihal Rancangan Batas- batas Daerah Lingkungan Kerja dan Daerah Lingkungan 
Kepentingan Pelabuhan Tarakan yang bertujuan untuk menjamin kepastian dalam penyediaan dan penggunaan tanah di Pelabuhan Tarakan.

Luas kawasan pelabuhan Tarakan berdasarkan SKB ialah 172.199.000 M² (Seratus Tujuh Puluh dua Juta Seratus Sembilan puluh sembilan ribu meter persegi) untuk batas Daerah Lingkungan Kerja Perairan Pelabuhan dan $43.000 \mathrm{M}^{2}$ ( Empat puluh tiga ribu delapan ratus meter persegi) untuk Batas Daerah Lingkungan Kerja Daratan Pelabuhan. Area Pelabuhan yang merupakan Daerah Lingkungan Kerja Daratan Pelabuhan akan diberikan dengan Hak Pengelolaan kepada Departemen Perhubungan Republik Indonesia atau Instansi yang ditunjuk oleh Menteri Perhubungan Republik Indonesia dalam hal ini PT. PELINDO IV Tarakan.

\section{Hak Pengelolaan (HPL) Daerah Lingkungan Kerja Pelabuhan HPL dalam Hukum Tanah Nasional}

Hak Pengelolaan diperoleh dari hak menguasai negara atas tanah yang sebagian kewenanganya dilimpahkan kepada pemegangnya untuk memanfaatakan tanah tersebut, serta pemegang HPL berwenang untuk menuntut agar pihak lain menghormati haknya dan dapat meminta perlindungan hukum terhadap pemanfaatan haknya. Selain itu pihak lain atau pihak ketiga yang berkeinginan untuk memanfaatkan bagian-bagian dari tanah HPL berkewajiban untuk mengadakan perjanjian tertulis dengan pemegang HPL. Beberapa ahli berpendapat bahwa HPL dalam sistematika hak- hak penguasaan atas tanah tidak dimasukkan dalam golongan hak- hak atas tanah. Pemegang HPL memang mempunyai kewenangan untuk menggunakan tanah yang diberi hak bagi kepentingan atau keperluan usahanya, tetapi itu bukanlah tujuan pemberian hak tersebut kepada subyek dari Hak Pengelolaan tersebut. Tujuan utamanya adalah bahwa tanah yang bersangkutan disediakan bagi penggunaan oleh pihak-pihak lain yang memerlukan sesuai jenis Peruntukannya seperti HPL Pelabuhan, HPL Otorita, HPL Perumahan, HPL Pemerintah Daerah, HPL Transmigrasi, HPL Instansi Pemerintah, dan HPL Industri/ Pertanian/ Pariwisata/ Perkeretaapian. ${ }^{8}$

Istilah Hak Pengelolaan dalam UUPA tidak disebutkan secara eksplisit dalam konsideran, diktum, batang tubuh maupun penjelasan Undang- Undang Nomor 5 Tahun

8 Maria S.W Sumardjono, "Hak Pengelolaan : Perkembangan, Regulasi, dan Implementasinya", Mimbar Hukum, Edisi Khusus, September 2007, Fakultas Hukum Universitas Gadjah Mada, Yogyakarta, h. 29. 
1960 tentang Peraturan Dasar Pokok- Pokok Agraria, namun hak pengelolaan dapat ditemukan pada penjelasan umum angka II Nomor 2 UUPA yang meyebutkan :

Negara dapat memberikan tanah yang demikian itu kepada seseorang atau badan hukum dengan suatu hak menurut peruntukannya dan keperluannya, misalnya hak milik, hak guna usaha, Hak Guna Bangunan, Hak Pakai atau memberikannya dalam pengelolaan kepada suatu badan penguasa (departemen, jawatan atau daerah swatantra) untuk digunakan bagi pelaksanaan tugasnya masing- masing.

Berdasarkan penjelasan UUPA tersebut terdapat istilah pengelola, namun pengertian pengelolaan disini bukan Hak Pengelolaan atau dalam bahasa belanda disebut Beheersrecht yang artinya Penguasaaan dan dalam sistematika hak-hak penguasaan atas tanah tidak dimasukkan dalam golongan hak-hak atas tanah. Pemegang Hak Pengelolaan mempunyai kewenangan untuk menggunakan tanah untuk keperluan usahanya, pemberian pengelolaan tanah pada badan penguasa yang dimaksud tidak secara tegas mengambarkan adanya hak yang diberikan oleh negara berupa hak penguasaan terhadap tanah tersebut, namun hanya bersifat pelimpahan sebagian wewenang atas hak menguasai negara atas tanah.

Hak Pengelolaan dapat dikategorikan sebagai hak atas tanah yang bersifat right to use tidak bersifat right of dispossal; ${ }^{9}$ Hak Pengelolaan yang merupakan perubahan dari hak penguasaan secara yuridis diatur dalam Peraturan Pemerintah Nomor 8 Tahun 1953 tentang Hak Penguasaan Tanah- Tanah Negara. Hak Penguasaan berisikan wewenang untuk merencanakan peruntukan atau penggunaan tanah tersebut; Menggunakan tanah tersebut untuk keperluan pelaksanaan tugasnnya; Menerima uang pemasukan/ ganti rugi dan atau uang wajib tahunan. ${ }^{10}$ Dari penjelasan tersebut bahwa wewenang yang diberikan pada pemegang Hak Pengelolaan tidak seperti hak atas tanah yang dapat dimiliki atau dikuasai secara langsung oleh seseorang atau badan dan adanya konsekuensi yang bersifat wajib yang harus dipenuhi kepada negara selaku pemberi hak tersebut dari hasil usahanya di atas tanah Hak Pengelolaan tersebut. Namun pada aspek perdata dari hak pengelolaan terlihat dari berubahnya fungsi pengelolaan menjadi hak. ${ }^{11}$ yang dalam konteks hak disini berupa kewenangan untuk mempergunakan tanah yang dikuasai oleh Negara dalam bentuk Hak Pengelolaan di karenakan adanya kebutuhan

${ }^{9}$ Urip Santoso I, Op. Cit, h. 178.

${ }^{10}$ Supriadi, Hukum Agraria, Sinar Grafika, Jakarta, 2015, h. 148. h. 34 .

${ }^{11}$ A.P Parlindungan, Komentar Atas Undang- undang Pokok Agraria, Mandar Maju, Bandung, 1993, 
yang bersifat praktis untuk keperluan usaha dengan tetap adanya penerimaan pada kas negara terhadapat tanah yang telah dilimpahkan sebagian wewenangnya dalam bentuk Hak Pengelolaan pada subyek Hak Pengelolaan tersebut.

Pada Peraturan Menteri Agraria Nomor 9 Tahun 1965 tentang Pelaksanaaan Konvensi Hak Penguasaan Atas Tanah Negara dan Ketentuan Ketentuan tentang Kebiaksanaan Selanjutnya, Pada Pasal 1 dinyatakan bahwa hak penguasaaan atau dalam istilah Belanda yaitu Beheersrecht yang merupakan istilah semula dari Hak Pengelolaan yang dipergunakan untuk keperluan sendiri dari Departemen- departemen, direktoratdirektorat dan daerah Swatantra dikonversikan menjadi Hak Pakai. Selanjutnya pada Pasal 2 ditetapkan bahwa selain untuk instansi sendiri tanah tersebut juga dimaksudkan untuk dapat diberikan dengan sesuatu hak kepada pihak ketiga, maka Hak Peguasaan itu dikonversi menjadi Hak Pengelolaan dan berlangsung selama tanah tersebut dipergunakan untuk keperluan Instansi yang bersangkutan. Pada Peraturan Pemerintah Nomor 1 Tahun 1967 tentang Pemberian Tugas dan Wewenang Agraria dalam Ketentuan Nomor IV ditetapkan sebagai berikut, yaitu Menteri Dalam Negeri atau Direktur Jenderal Agraria untuk dapat :

a.) Memberikan keputusan mengenai permohonan tanah Negara dengan Hak Pengelolaan oleh Badan Swatantra dan Badan- badan Pemerntah lainnya yag berisikan wewenang, selain untuk dipergunakan sendiri sebagai tanah yang bersangkutan, uga memberikannya kepada pihak- pihak lain dengan hak pakai menurut ketentuan khusus.

b.) Memberkan Keputusan mengenai permohonan untuk memperpanjang jangka waktu atau pelepasan Hak Pengelolaan tersebut. ${ }^{12}$

\section{Pendaftaran dan penghapusan Hak Pengelolaan (HPL)}

Hak Pengelolaan merupakan salah satu Hak atas tanah yang dapat di daftarkan dan terbitkan surat tanda bukti hak berupa sertipikat yang diatur dalam Peraturan Pemerintah Nomor 24 tahun 1997 tentang Pendaftaran Tanah, secara spesifik pendaftaran hak pengelolaan diatur oleh Pasal 9 Peraturan Menteri Agraria Nomor 9 Tahun 1965 yang menyatakan 
a) Hak Pakai dan Hak Pengelolaan tersebut yang sepanjang jangka waktunya melebihi 5 (lima) tahun didaftar menurut ketentuan- ketentuan Peraturan Pemerintah Nomor 10 Tahun 1961 Tentang Pendaftaran Tanah;

b) Jika ditentukan jangka waktunya maka hak tersebut dianggap akan berlangsung lebih dari 5 (lima) tahun;

c) Jika hak tersebut pada Pasal 1 dan 2 belum didaftara pada kantor pendaftaran tanah maka pemegang hak yang bersangkutan waib datang pada kantor pendaftaran tanah yang bersangkutan untuk mendaftarakan dengan mempergunakan daftar isian yang contohnya akan ditetapkan sendiri.

Adanya Peraturan Menteri Negara Agraria atau Kepala Badan Pertanahan Nasional Nomor 3 Tahun 1999 Tentang Pelimpahan Kewenangan Pemberian dan Pembatalan Keputusan Hak Atas Tanah Negara Pasal 2 ayat (1) menyatakan bahwa kewenangan pemberian hak atas tanah secara individual dan kolektif, serta pembatalan keputusan pemberian hak atas tanah dilimpahkan sebagian kepada Kepala Kantor Wilayah Badan Pertanahan Nasional Provinsi atau Kepala Kantor Pertanahan Kabupaten/ Kota . Pada Peraturan Menteri Dalam Agraria atau Kepala Badan Pertanahan Nasional Nomor 9 Tahun 1999 tentang Tata Cara Pemberian dan Pembatalan Hak Atas Tanah Negara dan Hak Pengelolaan Pasal 68 dan Pasal 70 menyebutkan bahwa, pengajuan permohonan Hak Pengelolaan diajukan secara tertulis kepada Menteri melalui Kantor Wilayah (Kanwil) Pertanahan tempat dimana letak tanah yang menjadi wilayah kerjanya. Pada Pasal 68 dijelaskan bahwa, permohonan Hak Pengelolaan dilakukan secara tertulis yang isinya memuat tentang Keterangan pemohon seperti nama badan hukum, tempat kedudukan serta akta pendirian dari badan hukum yang mengajukan permohonan.

Permohonan Hak Pengelolaan tersebut juga berisi tentang keterangan mengenai tanah yang menjadi obyek Hak Pengelolaan berupa data yuridis dan data fisik, adapun data yang dimaksud tersebut dapat berupa bukti kepemilikan dan atau bukti perolehan tanah berupa sertipikat penunjukan atau penyerahan dari pemerintah, akta pelepasan bekas tanah milik atau bukti perolehan tanah lainnya, letak batas- batas dan luasan yang terdapat pada surat ukur atau pada gambar situasi, keterangan jenis tanah (Pertanian atau non Pertanian), rencana penggunaan lahan, serta status tanahnnya (tanah hak atau tanah negara). Permohonan Hak Pengelolaan akan diajukan kepada Menteri melalui Kepala Kantor Pertanahan yang daerah kerjannya meliputi letak tanah yang bersangkutan, lebih lanjut Pasal 75 menjelaskan keputusan pemberian atau penolakan 
pemberian Hak Pengelolaan disampaikan kepada pemohonan melalui surat tercatat atau dengan cara lain yang menjamin sampainnya keputusan tersebut kepada yang berhak, namun jika melihat prosedur pendaftaran yang dijelaskan dalam Peraturan Menteri Agraria Nomor 9 Tahun 1965. Bahwa jangka waktu yang melebihi 5 tahun harus didaftarkan berarti dalam hal ini jangka waktu Hak Pengelolaan tidak ditentukan dan sangat panjang.

Sertipikat yang diterbitkan oleh Kepala Kantor Pertanahan Kabupaten/ Kota diatas Hak Pengelolaan pada dasarnya sama dengan sertipikat hak atas tanah yang diberikan langsung di atas tanah negara, namun yang membedakan adalah: ${ }^{13}$

a) Secara Formal pada sertipikat tanah yang diberikan diatas tanah Hak Pengelolaan tercantum penunjukan bahwa hak atas tanah yang diberikan kepada pihak ketiga berdiri atau berada di atas Hak Pengelolaan;

b) Untuk Perpanjangan, Pengalihan, Pembebasan atas tanah tersebut, lebih dahulu harus mendapat persetujuan dari pemegang Hak Pengelolaan.

PT. PELINDO IV Tarakan selaku instansi yang ditunjuk oleh Kementerian Perhubungan sebagai penerima Hak Pengelolaan telah melakukan pendaftaran dan menyelesaikan prosedur pendaftaran atau sertipikatnya di Kantor Pertanahan Nasional, hal tersebut dapat diketahui dengan telah dikeluarkannya Sertipikat Hak Pengelolaan oleh Kantor Pertanahan Kabupaten Bulungan Nomor 01 Tahun 1993 yang diterbitkan tanggal 21 Desember 1993 dengan luas 28. 144 M² (Dua puluh delapan ribu seratus empat puluh empat meter persegi). dari total tanah lingkungan kerja daratan pelabuhan atau Daerah Lingkungan Kerja Pelabuhan (DLKr) berdasarkan SKB Menteri Dalam Negeri dan Menteri Perhubungan RI Nomor 31 Tahun 1992 Nomor K.M 9 Tahun 1992 tentang batas- batas daerah Lingkungan Kerja Pelabuhan seluas $43.000 \mathrm{M}^{2}$ (Empat puluh tiga ribu delapan ratus meter persegi),

Dalam penyelesaian proses pendaftaran dan sertipikat HPL akan dikenakan biaya sesuai ketentuan Peraturan Pemerintah tentang jenis dan tarif atas jenis penerimaan negara bukan pajak yang berlaku pada Badan Pertanahan Nasional Republik Indonesia, dengan waktu penyelesaiaan 97 (sembilan puluh tujuh) hari. ${ }^{14}$ PT. PELINDO IV Tarakan menyelesaikan biaya admnistrasi atau membayar uang pemasukan sebesar Rp.

\footnotetext{
13Irawan Soerodjo, Hukum Pertanahan Hak Pengelolaan atas Tanah (HPL) Eksistensi, Pengaturan dan Praktik, Laksbang Mediatama, Yogyakarta, 2015, h. 97.

${ }^{14}$ Rusmadi Murad, Administrasi Pertanahan Pelaksanaan Hukum Pertanahan dalam Praktek Edisi Revisi, Mandar Maju, Bandung, 2013, h. 528.
} 
56.992.500, (Lima puluh enam uta sembilan ratus sembilan puluh dua ribu lima ratus rupiah) pada Kantor Pertanahan Kabupaten Bulungan. Terbitnya sertifikat tersebut secara otomatis telah memberikan kepastian hukum atas lahan yang menjadi Daerah Lingkungan Kerja Pelabuhan PT. PELINDO IV Tarakan dengan luasan yang sesuai terdapat dalam sertipikat tersebut, serta pihak PT. PELINDO IV Tarakan telah menerima akibat hukum yang timbul dari diterbitkannya sertipikat tersebut berupa kewenangan untuk mengelola dan memanfaatkan HPL tersebut sesuai fungsinya.

Selain pemberian Sertifikat terhadap Hak Pengelolaan, HPL tersebut pun dapat dicabut atau dihapuskan. Dicabutnya atau dihapusnya keputusan pemberian HPL berdampak hilangnya hak terhadap tanah negara yang telah diberikan kepada pemegang HPL sehingga status tanah itu secara otomatis berubah menjadi tanah negara atau tanah yang langsung dikuasai oleh negara. Penghapusan hak- hak atas tanah seperti hak- hak atas tanah seperti Hak Milik, Hak Pakai, Hak Guna Usaha atau Hak Guna Bangunan telah diatur dalam Undang- Undang Pokok Agraria, namun untuk penghapusan atau pencabutan HPL yang bukan merupakan produk dari UUPA diatur lebih lanjut pada Pada Peraturan Menteri Agraria atau Kepala Badan Pertanahan Nasional Nomor 9 Tahun 1999 tentang Tata Cara Pemberian dan Pembatalan Hak Atas Tanah Negara dan Hak Pengelolaan.

Pembatalan hak atas tanah tersebut meliputi dengan pembatalan keputusan pemeberian hak, sertipikat hak atas tanah dan/ atau keputusan yang dikeluarkan dalam rangka pengaturan penguasaan tanah. Pada Pasal 104 ayat (2) dijelaskan bahwa Pembatalan Hak Atas Tanah terjadi karena :

a) Terdapat cacat hukum administrasi dalam penerbitan keputusan pemberian dan/ atau sertipikat hak atas tanah; atau

b) Melaksanakan putusan pengadilan yang telah memiliki kekuatan hukum tetap.

Pembatalan Hak Atas Tanah termasuk HPL mengakibatkan putusnya hubungan hukum antara pemegang Hak dengan tanah yang dikuasainya. Pencabutan atau pembatalan khususnya HPL tidak berakibat akan terjadinya berpindah kepada pihak ketiga, melainkan Hak Pengelolaan tersebut menjadi hapus. Selain itu hapusnya Hak Pengelolaan juga dapat terjadi karena haknya dicabut kembali yang disebabkan oleh tanahnya tidak dipergunakan sesuai dengan tujuan pemberian haknya. ${ }^{15}$

15Ibid, h. 113. 
Menurut Budi Harsono suatu Hak atas tanah dapat dihapus jika dibatalkan oleh pejabat yang berwenang sebagai saksi terhadap tidak dipenuhinnya suatu kewajiban atau dilanggarnya suatu larangan oleh pemegang hak yang bersangkutan. Penyebab lain juga hapusnya Hak Pengelolaan adalah jika tanah tersebut musnah. ${ }^{16}$ Pejabat yang berwenang untuk mencabut Hak Pengelolan berdasarkan Peraturan Menteri Negara Agraria Nomor 9 Tahun 1999 adalah pemberi wewenag tersebut dalam hal ini Menteri Negara Agraria atau Kepala Badan Pertanahan Nasional. Adapun Musnahnya tanah dapat disebabkan terjadinya fenomena alam atau perubahan permukaan tanah dikarenakan bencana alam sehingga tidak dapat digunakan berdasarkan fungsi awal pemanfaat tanah tersebut. Pencabutan atau penghapusan Hak Pengelolaan berakibat tanah tersebut menjadi tanah yang dikuasai oleh negara, apabila tanah tersebut ingin dijadikan Hak Pengelolaan oleh pihak lain maka dilakukan permohonan kembali oleh pihak lain atau calon pemegang hak.

\section{Kewenangan atas tanah Hak Pengelolaan (HPL)}

Berdasarkan peraturan Perundang- Undangan yang berlaku di Indonesia, Wewenang yang diberikan kepada pemegang HPL diantaranya Pasal 6 Peraturan Menteri Agraria Nomor 9 Tahun 1965, Peraturan Menteri Dalam Negeri Nomor 5 Tahun 1974, Pasal 1 dan 2 Peraturan Menteri Dalam Negeri Nomor 1 Tahun 1977, serta Peraturan Pemerintah Nomor 33 Tahun 1997 menjelaskan wewenang yang melekat pada pemegang Hak Pengelolaan ialah:

a. Merencanakan peruntukan dan penggunaan tanah yang berpedoman pada Rencana Tata Ruang Wilayah (RTRW) yang ditetapkan oleh Pemerintah Kabupaten/ Kota berdasarkan Peraturan Daerah Kabupaten/ Kota setempat.

b. Menggunakan tanah untuk keperluan pelaksanaan tugasnya dan/ atau usahanya. Adapun bentuk penggunaan disini misalnya fasilitas umum, perumahan, pabrik, perkantoran dan kawasan industri lainnya.

c. Menyerahkan bagian- bagian tanah hak pengelolaan kepada pihak ketiga dan/ atau bekerjasama dengan pihak ketiga.

Sebelum berlakunya UUPA, pelabuhan diatur berdasarkan Stb. 1917 Nomor 464 mempunyai sesuatu hak yang diatur oleh perundang- undangan sebagaimana yang tercantum dalam Pasal 521 KUH Perdata, yaitu antara lain pantai, perairan dan

16Boedi, Harsono I, Op. Cit, h. 327. 
pelabuhan adalah milik negara dan perusahaan pelabuhan diserahkan untuk mengelola pelabuhan, perairan dan pantai- pantai yang ada. ${ }^{17}$ Berdasarkan Peraturan Pemerintah Nomor 69 Tahun 21 Tentang Kepelabuhanan, Daerah Lingkungan Kerja pelabuhan adalah adalah wilayah perairan dan daratan pada pelabuhan umum yang dipergunakan untuk menjamin keselamatan pelayaran. Daerah Lingkungan Kerja pelabuhan yang sebagian merupakan daratan yang berbatasan langsung dengan daerah perairan pelabuhan, akan berkaitan erat dengan penataan tata guna tanah dan hak- hak atas tanah. Hak atas Tanah yang akan diberikan pada PT. PELINDO IV Tarakan berupa tanah Hak Pengelolaan, yang kemudian menjadi Lingkungan Kerja Daratan Pelabuhan atau Daerah Lingkungan Kerja Pelabuhan (DLKr). Penetapan Daerah Lingkungan Kerja Pelabuhan PT. PELINDO IV Tarakan tersebut bersumber dari Surat Keputusan Bersama (SKB) Menteri Dalam Negeri dan Menteri Perhubungan RI Nomor 31 Tahun 1992 Nomor K.M 9 Tahun 1992 tentang batas- batas daerah Lingkungan Kerja Pelabuhan.

Pengajuan permohonan HPL untuk Daerah Lingkungan Kerja Pelabuhan Tarakan berdasarkan Surat Gubernur Kepala Daerah tingkat I Kalimantan Timur tanggal 13 Januari 1987 Nomor 651/626/ BPD. 1 BANG dan telah memenuhi ketentuan aturan yang menjadi rujukan pemberian Hak Pengelolaan (HPL), yaitu Peraturan Pemerintah Nomor 8 Tahun 1953 juncto Peraturan Menteri Agraria Nomor 9 tahun 1965 dan juncto Peraturan Menteri Agraria Nomor 1 Tahun 1966 dan Surat Keputusan Bersama (SKB) Menteri Dalam Negeri bersama Menteri Perhubungan tanggal 27 Desember 1969 Nomor 191 Tahun 1969/ SK. 83/0/1969 tentang penyediaan dan penggunaan tanah untuk keperluan pelabuhan. Dalam Surat Keputusan Bersama (SKB) Menteri Dalam Negeri dan Menteri Perhubungan tersebut, dijelaskan hak- hak dan wewenang yang dimiliki PT. PELINDO IV Tarakan atas tanah Daerah Lingkungan Kerja pelabuhan ialah :

1. Merencanakan peruntukan dan penggunaan tanah;

2. menggunakan tanah tersebut untuk keperluan pelaksanaan usahannya;

3. menyerahkan bagian- bagian dari tanah itu kepada pihak ketiga menurut persyaratan yang ditentukan oleh Menteri Perhubungan atau Pejabat yang ditunjuk, yang meliputi segi- segi peruntukan, angka waktu dan keuangannya, dengan ketentuan bahwa pemberian hak atas tanah kepada pihak ketiga

${ }^{17}$ Lovelly Dwina Dahen, "Analisis Yuridis Terhadap Hak- Hak Atas Tanah yang Berada di Atas Hak Pengelolaan Pelabuhan", Jurnal Ilmu Hukum, Volume 3 Nomor 1. 
tersebut dilakukan oleh pejabat Kantor Wilayah Badan Pertanahan Nasional yang berwenang sesuai dengan Peraturan Perundang- undagan yang berlaku;

4. memberikan izin untuk mendirikan bangunan kepada pihak ketiga dengan memperhatikan saran dari Pemerintah Daerah.

Sebelum PT. PELINDO IV Tarakan memperoleh HPL pada Daerah Lingkungan Kerja Pelabuhan tersebut, PT. PELINDO IV Tarakan terlebih dahulu harus memperhatikan ketentuan- ketentuan dalam hak milik atas tanah HPL yang terdiri dari Pembuatan Akta Pelepasan atau pernyataan pelepasan atau penyerahan hak pengelolaan oleh pemegang haknya. ${ }^{18}$ Ketentuan- ketentuan tersebut sesuai dengan Peraturan Pemerintah Nomor 24 Tahun 1997 tentang Pendaftaran Tanah dan Peraturan Menteri Agraria/ Kepala Badan Pertanahan Nasional Nomor 9 Tahun 1999 tentang Tata Cara Pemberian dan Pembatalan Hak Atas Tanah Negara dan Hak Pengelolaan.

Kewajiban PT. PELINDO IV Tarakan untuk mendaftarkan Daerah Lingkungan Kerja Pelabuhan pada Kantor Pertanahan Kabupatrn Bulungan merupakan suatu tindakan hukum yang harus dilakukan yang menimbulkan akibat hukum berupa perolehan HPL serta kewenangan yang melekat atas tanah HPL tersebut. Akibat hukum timbul dikarenakan suatu tindakan yang dilakukan untuk memperoleh suatu akibat yang dikehendaki oleh pelaku dan yang diatur oleh hukum. ${ }^{19}$ atau dapat dikatakan akibat hukum ialah akibat dari tindakan hukum, yang wujud dari tindakan hukum itu sendiri adalah : 20

1. Lahirnya, berubahnya atau lenyapnya suatu keadaan hukum;

2. Lahirnya, berubahnya atau lenyapnya suatu hubungan hukum, antara dua atau lebih subyek hukum, dimana hak dan kewajiban pihak yang satu berhadapan dengan hak dan kewajiban pihak lain;

3. Lahirnya sanksi apabila dilakukan tindakan yang melawan hukum.

Hak Pengelolaan atas tanah untuk kepentingan pelabuhan dan wewenang yang diperoleh PT. PELINDO IV Tarakan terhadap HPL tersebut, merupakan akibat hukum dari tindakan hukum yang dilakukan oleh PT. PELINDO IV Tarakan. Untuk memperoleh HPL tersebut tentunya tindakan hukum berupa pendaftaran dan penyelesaian proses sertifikasi untuk memperoleh Hak Pengelolan harus dilakukan terlebih, selain itu PT.

18Urip Santoso, "Penggunaan Tanah Hak Pengelolaan oleh Pihak Ketiga”, Jurnal Dinamika Hukum Volume 13, Nomor 2, Mei 2013, h. 291.

${ }^{19}$ R. Soeroso, Pengantar Ilmu Hukum, Sinar Grafika, Jakarta, 2011, h. 295.

20Ibid 
PELINDO IV Tarakan memiliki kewajiban untuk menyelesaikan kewajiban yang dibebankan sebelum memperoleh sertipikat Hak Pengelolaan. Adapun kewajiban yang harus dipenuhi sesuai dengan yang diamanatkan Diktum Keempat dalam Surat Keputusan Bersama (SKB) Menteri pada PT. PELINDO IV Tarakan ialah terlebih dahulu :

1. terhadap tanah yang masih dikuasai Pihak Ketiga harus terlebih dahulu dibebankan oleh Perusahan Umum Pelabuhan atau PT. PELINDO IV Tarakan;

2. Penunjukan dan Penetapan tugu batas dari Daerah Lingkungan Kerja Pelabuhan di lapangan dilaksanakan berdasarkan koordinat geografis pada peta oleh Panitia Penunjuk Batas yang terdiri dari Perum Pelabuhan IV/ PT. PELINDO IV Tarakan dan Pemerintah Daerah, yang dalam pelaksanaannya dimungkinkan adanya penyesuaian dengan keadaan lapangan;

3. Pengukuran dan uraian batas- batas Daerah Lingkungan Kerja Pelabuhan dilaksankan oleh Kantor Wilayah Badan Pertanahan Nasional setempat sesuai dengan Peraturan Perundangan yang berlaku.

Dari ketiga ketentuan yang harus dipenuhi oleh PT. PELINDO IV Tarakan untuk memperoleh HPL diatas Daerah Lingkungan Kerja Pelabuhan sesuai Surat Keputusan Bersama (SKB) Menteri, pihak PT. PELINDO IV Tarakan hanya memenuhi sebagian dari kewajiban tersebut. Hal ini dapat dilihat dengan proses pendaftaran dan pensertipikatan yang dilakukan oleh PT. PELINDO IV Tarakan tidak sesuai dengan luasan wilayah kerja daratan yang dijelaskan dalam Surat Keputusan Bersama (SKB) Menteri tersebut, yaitu seluas $43.000 \mathrm{M}^{2}$ (Empat puluh tiga ribu delapan ratus meter persegi) total tanah yang akan diberikan dalam bentuk HPL.

Proses Pendaftaran tanah yang telah dilakukan oleh PT. PELINDO IV Tarakan sampai dengan keluarkannya Sertipikat Hak Pengelolaan oleh Kantor Pertanahan Kabupaten Bulungan, menetapkan tanah Daerah Lingkungan Kerja Pelabuhan yang menjadi kewenangan dengan Hak Pengelolaan PT. PELINDO IV Tarakan sebatas lahan yang dinyatakan dalam sertipikat HPL Nomor 01 Tahun 1993 dengan luasan 28. 144 M² $^{2}$ (Dua puluh delapan ribu seratus empat puluh empat meter persegi). Sementara untuk wilayah yang belum diakomodir dalam sertipikat HPL, belum ada kewenangan yang melekat secara langsung dari PT. PELINDO IV Tarakan atas tanah Daerah Lingkungan Kerja pelabuhan tersebut untuk digunakan sebagai penunjang pelaksanaan usahannya; dan/atau menyerahkan bagian- bagian dari tanah serta memberikan izin untuk mendirikan bangunan kepada pihak ketiga. 


\section{PENUTUP}

\section{Kesimpulan}

Kewenangan dari pihak PT. PELINDO IV Tarakan atas tanah Daerah Lingkungan Kerja Pelabuhan yang terdiri atas daratan ialah sesuai dengan kewenangan yang melekat pada tanah dengan status Hak Pengelolaan (HPL). Yaitu kewenangan untuk merencanakan pemanfaatan tanah tersebut untuk menunjang kegiatannya, menggunakan atau memanfaatkan tanah tersebut untuk kepentingan usahannya, memberikan sebagian hak atas Tanah kepada pihak ketiga dengan meknisme perjanjian dan memberikan izin untuk mendirikan bangunan di atas tanah dengan status HPL tersebut. Hak Atas Tanah berupa HPL Daerah Lingkungan Kerja Pelabuhan PT. PELINDO IV Tarakan terlebih dahulu didaftarkan sesuai dengan Peraturan Pemerintah Nomor 24 Tahun 1997 Tentang Pendaftaran tanah, serta memperhatikan isi dari SKB Menteri Perhubungan dan Menteri Dalam Negeri terkait ketentuan dan persyaratan yang harus dipenuhi atau diselesaikan terlebih dahulu oleh PT. PELINDO IV Tarakan untuk memperoleh Hak Atas Tanah berupa HPL pada Daerah Lingkungan Kerja pelabuhan yang ditetapkan dalam SKB. Terbatas lahan yang telah didaftarkan dengan Hak Pengelolaan pada Kantor Pertanahan, tentunya berdampak pada terbatasnya kewenangan PT. PELINDO IV Tarakan terhadap keseluruhan Daerah Lingkungan Kerja pelabuhan.

\section{Saran}

PT. PELINDO IV Tarakan perlu melakukan langkah- langkah strategis berupa koordinasi dengan Pemerintah Kota Tarakan terkait penyusunan Peraturan Daerah tentang Rencana Tata Ruang Wilayah Kota Tarakan. Hal tersebut bertujuan agar Daerah Lingkungan Kerja pelabuhan yang ditetapkan dalam Surat Kepurtusan Bersama (SKB) Menteri Dalam Negeri dan Menteri Perhubungan tersebut dapat diakomodir dalam Rencana Tata Ruang Wilayah Kota Tarakan, sehingga tidak ada lagi penyalahgunaan tata guna tanah atau penyesuaian rencana tata ruang untuk Daerah Lingkungan Kerja Pelabuhan.

\section{Daftar Pustaka}

\section{Buku- buku}

A.P Parlindungan, Komentar Atas Undang- undang Pokok Agraria, Mandar Maju, Bandung, 1993.

Arie Sukanti Hutagalung dan Markus Gunawan, Kewenangan Pemerintah di Bidang Pertanahan, Rajawali Pers, Jakarta, 2009. 
Boedi Harsono, Hukum Agraria Indonesia Sejarah Pembentukan Undang- Undang Pokok Agraria, Isi dan Penjelasannya, Djambatan, 2003.

Elfrida Gultom, Refungsionalisasi Pengaturan Pelabuhan untuk Meningkatkan Ekonomi Nasional, Raja Grafindo Persada, 2007.

G. Kertasapoetra, Masalah Pertanahan di Indonesia, Rineka Cipta, Jakarta, 1992.

Ghansham Anand, Karakteristik Jabatan Notaris di Indonesia, Zifatama Publisher, Sidoarjo, 2014.

Hans Kelsen, Teori Umum Tentang Hukum dan Negara, Nusa Media, Bandung, 2014.

Jimly Assyddiqie, Perihal Undang-Undang, Konpress, Jakarta, 2006.

John Salindeho, Masalah Tanah dalam Pembangunan, Sinar Grafika, Jakarta, 1988.

Muhammad Bakri, Hak Menguasai Tanah Oleh Negara Paradigma Baru Untuk Reforma Agraria, Citra Media, Jakarta, 2007.

R. Soeroso, Pengantar Ilmu Hukum, Sinar Grafika, Jakarta, 2011.

Rahardjo Adisasmita, Pembangunan Kelautan dan Kewilayahan, Graha Ilmu, Yogyakarta, 2006.

Rusmadi Murad, Administrasi Pertanahan Pelaksanaan Hukum Pertanahan dalam Praktek Edisi Revisi, Mandar Maju, Bandung, 2013.

Safri Nugraha, dkk, Hukum Administrasi Negara, Universitas Indonesia, Depok, 2007.

Supriadi, Hukum Agraria, Sinar Grafika, Jakarta, 2015.

\section{Jurnal Hukum}

Lovelly Dwina Dahen, “Analisis Yuridis Terhadap Hak- Hak Atas Tanah yang Berada di Atas Hak Pengelolaan Pelabuhan”, Jurnal Ilmu Hukum, Volume 3 Nomor 1.

Maria S.W Sumardjono, "Hak Pengelolaan : Perkembangan, Regulasi, dan Implementasinya”, Mimbar Hukum, Edisi Khusus, September 2007, Fakultas Hukum Universitas Gadjah Mada, Yogyakarta.

Urip Santoso, "Penggunaan Tanah Hak Pengelolaan oleh Pihak Ketiga", Jurnal Dinamika Hukum Volume 13, Nomor 2, Mei 2013. 